\title{
The Impact of Land Use Change for Greenhouse Gas Inventories and State-Level Climate Mediation Policy: A GIS Methodology Applied to Connecticut
}

\author{
Linda Powers Tomasso, Mark Leighton \\ Sustainability and Environmental Management Program, Harvard University, Cambridge, USA \\ Email: tomasso@hsph.harvard.edu
}

Received 1 September 2014; revised 8 October 2014; accepted 22 October 2014

Copyright (C) 2014 by authors and Scientific Research Publishing Inc.

This work is licensed under the Creative Commons Attribution International License (CC BY). http://creativecommons.org/licenses/by/4.0/

(c) (i) Open Access

\begin{abstract}
Greenhouse gas (GHG) inventories conducted at state and regional levels serve to quantify longterm emissions trends and set benchmarks against which to evaluate the effectiveness of state government-mandated emissions reductions. GHG inventories which incompletely account for land use, land change, and forestry (LUCF) due to insufficient measurement tools discount the value of terrestrial carbon (C) sinks. In consequence, sink preservation is often omitted from regional land use planning. This paper proposes an accounting methodology which estimates foregone $C$ sequestration derived LUCF change in the southern New England State of Connecticut (CT). The Natural Capital Project's InVEST program provided a template for modeling $C$ storage and sequestration for CT's land class categories. LandSat mapping of long-term land cover patterns in CT conducted by CLEAR at the University of CT served as input data for InVEST computer modeling of $C$ sequestration, both realized and foregone due to LUCF. The results showed that: 1) Land converted from high $C$ density forestland to low density $C$ land cover classes reduced the rate of $C$ sequestration loss at 4.62 times the rate of forest reduction. Forest loss of $3.83 \%$ over twenty-five years was responsible for foregone $C$ sequestration equivalent to $17.68 \%$ of total 2010 sequestration. 2) Accumulating $C$ stocks pushed total annual sequestration from a 1985 baseline level of 866 $\mathrm{MMTCO}_{2}$ to $1116 \mathrm{MMTCO}_{2}$ by 2010-a $250 \mathrm{MMTCO}_{2}$ increment. 3) C sequestration from forest loss since 1985 would have yielded additional sequestration of $53.74 \mathrm{MMTCO}_{2}$ by 2010 . By 2002 , foregone yield surpassed CT's annual fossil fuel emissions, currently at $40 \mathrm{MMTCO}_{2}$. 4) Preservation of forest $\mathrm{C}$ stocks over time becomes the determining factor for influencing biomass $\mathrm{C}$ sequestration levels. Deciduous forests have a preponderant influence on $\mathrm{CO}_{2}$ budgets. The ground-up methodology to quantify land-based $C$ sequestration presented here demonstrates the influence of forest biomass in state-level $\mathrm{C}$ mitigation efforts useful to climate-oriented policy makers.
\end{abstract}




\section{Keywords}

\section{Carbon Sequestration, Forest Carbon Density, Climate Change, GIS Land Mapping, Land Use Change}

\section{Introduction}

In the absence of a national policy to lower net GHG emissions, deliberate policies in the US have instead been enacted at the state level. State energy policy makers and their constituents can better understand the range and scope of local emissions sources which feed climate warming trends through periodic greenhouse gas (GHG) accounting. Measuring emissions levels also establishes the baseline by which states can benchmark mandatory reduction targets. Eighteen US states have passed global warming reporting requirements to track state-based contributions to climate change, with three more state reporting mandates in progress [1]. As example, the Connecticut General Assembly's 2008 passage of Public Act 08-98, an Act Concerning Connecticut Global Warming Solutions (GWSA), introduced a triennial GHG inventory reporting requirement for that state [2]. The complexity of information behind emissions data collection, as well as the need for standardization of collection protocols among states for comparison at the federal level, has given rise to default data aggregators such as the US Environmental Protection Agency's (EPA) State Inventory Tool (SIT) [3]. The EPA SIT is the principal data collection tool for assembling state-level GHG inventories using data collected by US federal agencies and default estimates of $\mathrm{C}$ content and combustion efficiencies. EPA bases the land use, change and forest (LUCF) module of the SIT on GHG guidelines developed for country-wide assessment of land-based C sinks [4]. This approach requires a consistent, comprehensive division of land-based biomass according to the six main IPCC land use categories - forest land, cropland, grassland, settlements, wetlands and other lands - but does not provide single states the measurement tool to assess ground-level changes in biomass that alter $\mathrm{C}$ accounting results over time.

Many public agencies and research institutions have developed proprietary methodologies for assessing the impacts of GHG emissions on the atmosphere, some of which include methods to account for LUCF C sinks [5]-[7]. Assessment tools have varied, as have the scopes of application, results and conclusions. CT utilizes the EPA SIT, with its "top-down" approach to GHG accounting, except in the LUCF sector since the SIT LUCF module has not yielded consistent land use accounting results [8]. Assumed changes in LUCF accounting methodology reported forest $\mathrm{C}$ flux divergent in the extreme and which converted the sector from $\mathrm{C}$ sink to source between 1997 and $1999^{1}$. Reporting uncertainty has resulted in the LUCF sector's omission from subsequent state inventory protocols until better methodologies could be identified.

Sohl et al. [9] call for a national, consistent land use methodology to measure C flux, offering a prototype which demonstrates LUCF change based on biogeochemical modeling. The US Geological Survey in turn establishes emissions profiles for four specific US eco-regions using the FORE-SCE model to spatially map downscaled scenarios which would contribute to a national assessment of C stocks [10]. However, neither of these novel approaches to land-use emissions accounting is user-friendly at the level of state GHG inventory assembly.

The availability of cumulative land use data in CT over a twenty-five year span elucidates how long-term loss of biomass through sprawling land conversion compromises urgent policy goals of slowing global warming. Mapping data gathered at five-year periodic intervals provides consistent opportunity to analyze transitional land change dynamics. The land cover classes most heavily impacted by land conversion are the state's terrestrial carbon (C) sinks-most prominently forests, but also green fields, soils, and above- and below-ground biomass. While the environmental role of these $C$ sinks to climate regulation is well understood, methods to quantify their contribution to regional $\mathrm{C}$ budgets to date have largely been ignored due to the absence of reliable $\mathrm{C}$ accounting. This study seeks to address the weakness surrounding C sink accounting by proposing a ground-up methodology to quantify land-based $C$ sequestration which can used by climate-oriented policy makers.

Research on emissions increases from development-related land cover change supports the proposition that LUCF should play a greater role in GHG reduction strategies [11]-[14]. From an ecological perspective, land converted from both forests and farmland implies loss of wildlife habitat, habitat fragmentation, deterioration of

\footnotetext{
${ }^{1}$ Under the SIT reporting completed since 2009, CT’s LUCF sector has returned to being a C sink.
} 
air and water quality, groundwater run-off from fertilizers and pesticide, impeded groundwater recharge with the expansion of impervious surfaces, and disappearance of farmland. From a global warming perspective, land use characterized by low development density impacts the region's GHG profile, raising emissions from lengthened car travel, deterring public transit use, and increasing the minimum zoning requirements for property and, often in consequence, the $\mathrm{C}$ footprint of individual households. From a social equity standpoint, the continued trend toward outlier development diverts state and federal monies away from existing infrastructure improvement in older, inner-core communities in need of reinvestment and toward peripheral development, fueling the cycle of sprawl through newly-lain access to low-density areas [15]-[17]. Satellite land mapping supplies grounds to conclude that indiscriminate land use both drives GHG increases from mobile sources and exacerbates these dynamics by reducing the capacity for terrestrial C storage within the same landscape [18].

\section{Study Site}

New England states have seen a downturn in secondary forest recovery since 1970 [19]. CT has witnessed an increasing amount of undeveloped forest land being converted to development from 1985 to 2010 [20]. Land development encompasses not just residential and commercial building as well as roads, subdivisions and other incursive forms of urban and suburban land use. Land conversion in CT has been piecemeal, incremental and often decentralized at the level of township or property owner, masking the long-term regional impact of development and deforestation. Forest conversion to low-density housing (6- 25 homes $\left./ \mathrm{km}^{2}\right)$ was considered the fastest growing driver of New England's land cover change over this period [21]. In-state population growth is a key indicator value when gauging the efficiency of Connecticut's residential land development. US Census data reveals a highly skewed growth ratio of population growth in CT to developed land use, using a low-threshold housing development density of at least one housing unit per four acres to plot land development by census tract. In percentage terms, rates of land development grew at roughly eight times the population increase over the period 1970-2000 [21] (Figure 1). As a point of contrast, the Pacific Coastal Region forecasts forest cover reduction of four percent for the fifty-year period of 1997 to 2050 [22]. Over the next decades, CT's ratio of forest lost to population growth is expected to exceed Washington's by six-to-one, without accounting for future demographic shifts west.

CT lies in the wet, temperate climate zone of southern New England at $40^{\circ} 58^{\prime} \mathrm{N}$ to $42^{\circ} 3^{\prime} \mathrm{N}$ and $71^{\circ} 47^{\prime} \mathrm{W}$ to $73^{\circ} 44^{\prime} \mathrm{W}$. Elevation varies from sea level along the southern coast of Long Island Sound to 2316' (706 m) in the northwest corner adjoining New York and Massachusetts. CT is known for its attractive landscapes of densely forested hills. Forestlands cover 1.76 million acres $\left(2742\right.$ miles $\left.^{2}\right)$ [20], 80\% of which are deciduous forests. Deciduous forests represent the largest $\mathrm{C}$ stock in $\mathrm{CT}$, hovering just below one-half of the combined total for all land use classes in 2010. Twenty percent of CT's forest land is classified as urban forests located near or within urban zones; half (49\%) of these forests lie within 100 yards of hard development or agriculture [23]. New London

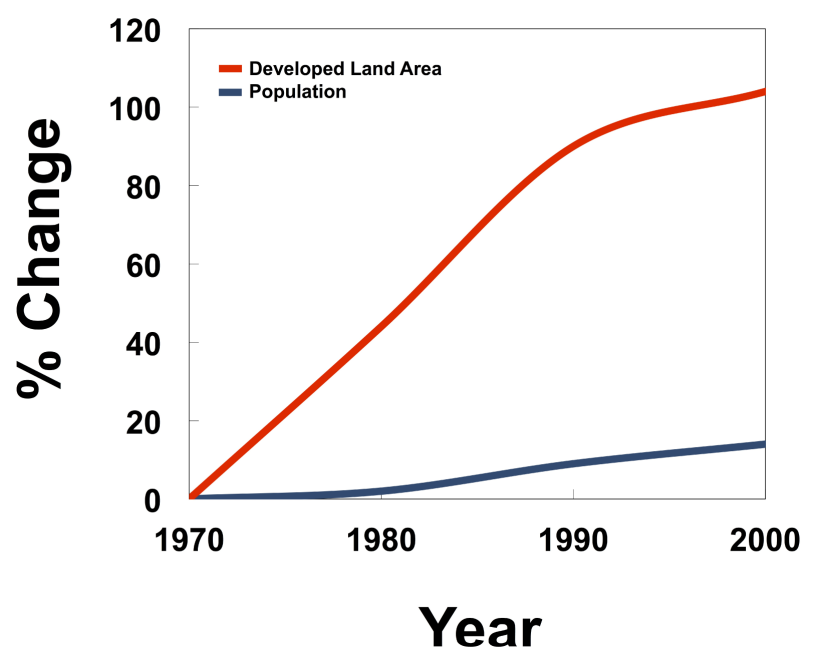

Figure 1. Percentage land change v population growth in CT, 1970-2000. 
County abutting CT's southern border is forecast to lose between $40 \%$ - $63 \%$ of private forestlands to land conversion and development by 2031, a prediction similar for New England's mid-coastal region [19]. Heavy development, rapid forest conversion and increasing sprawl extending from aging commercial arteries will continue to endanger Southern New England's coastal forests. Changing land cover in CT over the period 1985-2010 shows clear growth in developed areas (red) concentrated along the CT River valley dividing the state as well as its southern coastline (Figure 2).

\section{Research Methods}

The land use component of a state GHG inventory ideally reflects localized data gathered through satellite mapping similar to the type used under the REDD mechanism (Reducing Emissions from Deforestation in Developing Countries) to document avoided deforestation. To employ the REDD approach locally, satellite mapping data of state-wide land cover would be necessary to facilitate a "bottom-up" alternative to the SIT LUCF module. The Center for Land Use Change and Research (CLEAR) at the University of Connecticut (UConn) had designed a geospatial mapping methodology for NASA through the use of satellite data to monitor land change over time dating from the early 1980s [20]. The results of this long-term mapping project provided the landscape-scale data set to model changes to the state's terrestrial C sinks. CLEAR's satellite mapping model demonstrates the effects of development on CT's wooded landscape. The diagnostic value of CLEAR's satellite mapping project is widely accredited in documenting the imprint of urban sprawl [24]-[27] but had not previously been applied to estimate changes to terrestrial C sinks in CT.

The InVEST Carbon Storage and Sequestration computer model, developed at Stanford University's Wood Institute for the Environment and the Natural Capital Project [28] provided the simulation software to quantify and track terrestrial C storage in CT. The InVEST Version 2.5.3 model uses a raster data set drawn from land cover maps of the type produced by Project CLEAR in an ARC-MAP format [29]. A second required data set for modeling changes to sequestered $\mathrm{C}$ is an estimate of $\mathrm{C}$ pool valuations for each of the LUCF classes, assembled from the scientific literature on C density and terrestrial C capture specific to Southern New England forest eco-systems.

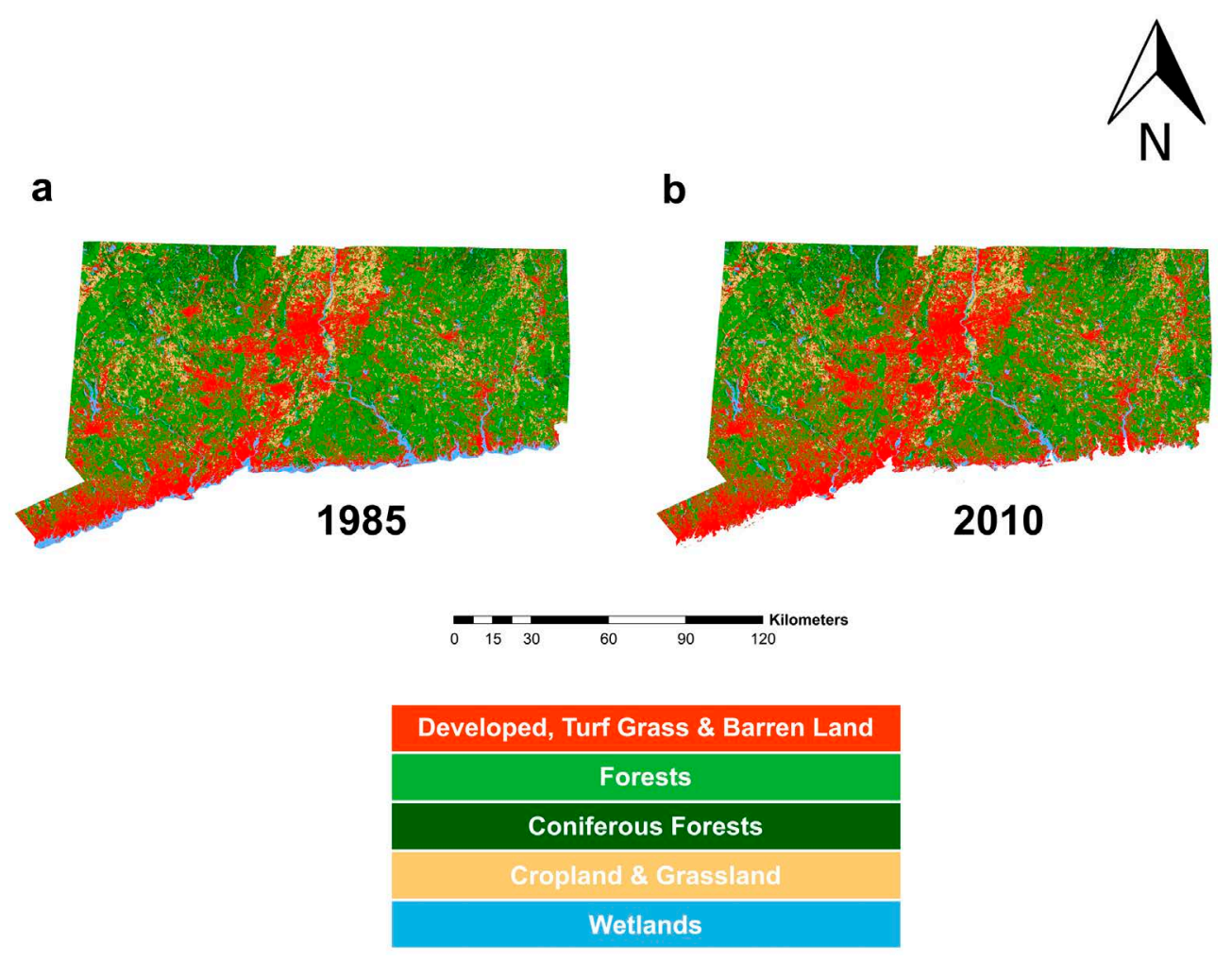

Figure 2. ArcGIS modeling of changes in LUCF land cover classes in CT, 1985 (left) v 2010 (right). 


\subsection{Estimating Land Cover Changes and Carbon Stocks by Vegetation Type}

CLEAR's GIS raster dataset of land cover use captured six measurement intervals across the period 1985-2010, with a LUCF code for each cell. Twelve land cover classes applied to CT: Developed, Turf \& Grass, Other Grasses, Agricultural Field, Deciduous Forest, Coniferous Forest, Water, Non-forested Wetland, Forested Wetland, Tidal Wetland, Barren, and Utility (Forest) [20]. We elaborated a matrix of LUCF classes to evaluate C stored in each of the four fundamental pools for each class: above-ground biomass, below-ground biomass, soil, and dead organic matter (Table 1). C stock values were prepared for the four $\mathrm{C}$ pools in accordance with the methodology given by the InVEST users' manual [28] and the IPCC [7]. Measured acreage of the twelve land cover classes plotted by Project CLEAR provided estimates for terrestrial C pool sizes in CT.

CLEAR's method of producing remotely sensed land cover maps is unique in its use of "cross-correlation analysis” to solve for the temporal and technical inconsistencies which occur in recurrent long-term satellite data collection [18]. This analytical approach increases the accuracy of measuring LandSat imagery captured in a given time interval against comparable data sets. The 30-meter resolution suitable for regional analysis has been maintained across the twenty-five years of the study to allow for spatially and spectrally consistent data comparison. The scale of CLEAR's Landsat image is set at about 185 kilometers per side in order to capture almost the entire state in a single image [20]. Data were made available as Connecticut State Plane Coordinates, NAD 83, in units of feet. Data reclassification to double band file format allowed overlay of the LandSat raster files onto a vector-based ArcGIS program (ESRI 2012) to create an ArcMap 10.1 of land cover changes in CT.

The table of $\mathrm{C}$ pools was compiled from evaluation of published scientific literature on $\mathrm{C}$ storage and sequestration particular to the various land use classes. Data on $\mathrm{C}$ pools were obtained through field estimates from local plot studies, meta-analyses on specific habitat types or regions, commissioned by government agencies, or from research conducted by Harvard-associated foresters. C storage was set equal to published C storage values, or the mean of published storage values for each LUCF class. A US Forest Service 2007 report was the sole source found which documented all four C stock quadrants by species for Southern New England forests, and so, with some accounting for species density, became the basis of our forest $\mathrm{C}$ values [23]. Most if not all of $\mathrm{C}$ stock estimates drew from research conducted within 50 - 100 miles north of CT (e.g., Harvard Forest), the one exception being $\mathrm{C}$ stock values for mid-Atlantic wetlands due to the absence of New England-specific references.

A baseline level of annual C increase of $2.5 \mathrm{MgC} \mathrm{ha}^{-1} \cdot \mathrm{y}^{-1}$ [30] was used to model C sequestration from deciduous forest growth; $3.0 \mathrm{MgC} \cdot \mathrm{ha}^{-1} \cdot \mathrm{y}^{-1}$ served as the coniferous baseline for old-growth eastern hemlock forests in central New England. Both values fell on the lower end of the range of estimated annual C storage in New England [31]-[34].

The Office of Soil Sampling at the CT Agricultural Experiment Station supplied C soil values for all land cover categories based on measurements of organic matter obtained by the loss-on-ignition method from plot studies of hundreds of forest sites in CT in 2012 [35]. The conversion rate of organic matter to C within the $15 \%$ - 30\% range was found typical for soil with CT's higher levels found in litter. Soil organic matter (SOM) approximations were confirmed by the State of CT Office of Soil Sampling as within acceptable range for modeling terrestrial C sequestration [35].

To capture the uncertainty apparent from the range of estimates for statewide forest growth rates, sensitivity analyses were conducted in which the parameters of biomass growth varied by both ten and forty percent above and below baseline value. The effects of variation from baseline biomass growth rates were applied to the forest $\mathrm{C}$ capture component of the model. A separate sensitivity analysis was run to estimate a ten percent lower and upper limit scenario on the underlying $\mathrm{C}$ stocks in land class types altered by annual biomass growth (grasses; deciduous, coniferous, and utility forests; forested wetland) as well as soil sedimentation and accretion (deciduous, coniferous, and utility forests; non-forested and forested wetlands). These biodynamic sensitivity values were plotted as a series of nineteen individual arrays (baseline, plus A-R) for each of the CLEAR land data sets (1985-2010) and inputted into the InVEST model of C sequestration. The resulting complete $C$ stock valuations were then layered onto a GIS ArcMap.

\subsection{Dynamics of Carbon Sequestration}

Using the same computing methodology, levels of $\mathrm{C}$ sequestration foregone due to land cover change were modeled and compared with the results of total $\mathrm{C}$ sequestered, in $\mathrm{CO}_{2}$ equivalents, for each of the CLEAR inventory intervals. For this comparison, the $2010 \mathrm{C}$ stock values and the 1985 CLEAR land use raster were 
Table 1. Matrix of carbon stock values for CT's twelve land cover classes, with published references for selected values, used as input data for InVEST carbon storage and sequestration modeling of LUCF. All values measured in megagrams of carbon per hectare per year.

\begin{tabular}{|c|c|c|c|c|c|c|c|c|}
\hline \multirow[b]{2}{*}{ Category } & \multicolumn{2}{|r|}{ Carbon (above) } & \multicolumn{2}{|r|}{ Carbon (below) } & \multicolumn{2}{|r|}{ Carbon (soil) } & \multicolumn{2}{|r|}{ Carbon (dead) } \\
\hline & Value & Reference & Value & Reference & Value & Reference & Value & Reference \\
\hline Developed & 0.2 & $\begin{array}{l}\text { Pouyat et al. } \\
\text { (2006) [36] }\end{array}$ & 0.59 & $\begin{array}{l}\text { Pouyat et al. } \\
\text { (2006) [36] }\end{array}$ & 33 & $\begin{array}{l}\text { Pouyat et al. } \\
\text { (2002) [37] }\end{array}$ & 0 & - \\
\hline \multirow{3}{*}{$\begin{array}{l}\text { Turf \& } \\
\text { grass }\end{array}$} & 0.9 & $\begin{array}{l}\text { Qian \& Follett } \\
\text { (2012) [38] }\end{array}$ & 9.11 & $\begin{array}{l}\text { Qian \& Follett } \\
\text { (2012) [38] }\end{array}$ & 110 & $\begin{array}{l}\text { Pouyat et al. } \\
\text { (2002) [36] }\end{array}$ & 0 & - \\
\hline & & $\begin{array}{c}\text { Rossi (2010) } \\
{[39]}\end{array}$ & & Rossi (2010) [39] & & $\begin{array}{l}\text { Post \& Kwon } \\
\text { (2005) [40] }\end{array}$ & & \\
\hline & & & & & & $\begin{array}{l}\text { Qian, Follett \& Kimble } \\
\text { (2010) [41] }\end{array}$ & & \\
\hline \multirow{3}{*}{$\begin{array}{l}\text { Other } \\
\text { grasses }\end{array}$} & 0.33 & $\begin{array}{l}\text { Post \& Kwon } \\
\text { (2005) [40] }\end{array}$ & 0.89 & $\begin{array}{l}\text { Pouyat et al. } \\
\text { (2006) [36] }\end{array}$ & 80.52 & $\begin{array}{l}\text { Compton \& Boone } \\
\text { (2002) [42] }\end{array}$ & 0.2 & $\begin{array}{l}\text { Conant et al. } \\
\text { (2001) [43] }\end{array}$ \\
\hline & & & & $\begin{array}{l}\text { Birdseye \& Heath } \\
\quad \text { (1992) [44] }\end{array}$ & & $\begin{array}{c}\text { Post \& Kwon } \\
\text { (2005) [40] }\end{array}$ & & \\
\hline & & & & & & Lal et al. (1999) [45] & & \\
\hline \multirow{3}{*}{$\begin{array}{l}\text { Agricultural } \\
\text { field }\end{array}$} & 5.2 & Raciti (2012) [46] & 0.89 & $\begin{array}{l}\text { Pouyat et al. } \\
\text { (2006) [36] }\end{array}$ & 60 & $\begin{array}{l}\text { Compton \& Boone } \\
\text { (2002) [42] }\end{array}$ & 1.7 & $\begin{array}{l}\text { West \& Post } \\
(2002)[47]\end{array}$ \\
\hline & & $\begin{array}{l}\text { Davidson et al. } \\
\text { (2002) [48] }\end{array}$ & & $\begin{array}{l}\text { Birdseye \& Heath } \\
\quad \text { (1992) [44] }\end{array}$ & & $\begin{array}{l}\text { Post \& Kwon } \\
\text { (2000) [40] }\end{array}$ & & \\
\hline & & & & & & Lal (2008) [49] & & \\
\hline \multirow{5}{*}{$\begin{array}{l}\text { Deciduous } \\
\text { forest }\end{array}$} & 109.8 & $\begin{array}{l}\text { Butler et al. } \\
\text { (2011) [23] }\end{array}$ & 50.5 & $\begin{array}{l}\text { Butler et al. } \\
\text { (2011) [23] }\end{array}$ & 78.5 & $\begin{array}{l}\text { Bradford et al. (2009) [31] } \\
\text { Bradford (2010) [32] }\end{array}$ & 31.4 & $\begin{array}{l}\text { Smith \& Heath } \\
\text { (2002) [50] }\end{array}$ \\
\hline & & $\begin{array}{c}\text { Bradford et al. } \\
(2009)[31] \\
\text { Bradford (2010) [32] }\end{array}$ & & $\begin{array}{c}\text { Bradford et al. } \\
(2009)[31] \\
\text { Bradford (2010) [32] }\end{array}$ & & $\begin{array}{l}\text { McGuire et al. } \\
\text { (1999) [33] }\end{array}$ & & $\begin{array}{l}\text { Compton \& Boone } \\
\text { (2007) [42] }\end{array}$ \\
\hline & & $\begin{array}{l}\text { McGuire et al. } \\
\text { (1999) [33] }\end{array}$ & & $\begin{array}{l}\text { Luyssaert et al } \\
\text { (2007) [51] }\end{array}$ & & Lal (2005) [52] & & \\
\hline & & $\begin{array}{l}\text { Smith \& Heath } \\
\text { (2002) [50] }\end{array}$ & & & & & & \\
\hline & & Wofsy (1993) [34] & & & & & & \\
\hline \multirow{4}{*}{$\begin{array}{l}\text { Coniferous } \\
\text { forest }\end{array}$} & 95.4 & $\begin{array}{l}\text { McGuire et al. } \\
\text { (1995) [33] }\end{array}$ & 43.9 & $\begin{array}{c}\text { Luyssaert et al (2007) } \\
\text { [51] }\end{array}$ & 52.6 & $\begin{array}{l}\text { McGuire et al } \\
\text { (1995) [33] }\end{array}$ & 31.1 & $\begin{array}{l}\text { Smith \& Heath } \\
\text { (2002) [50] }\end{array}$ \\
\hline & & $\begin{array}{l}\text { Butler et al. } \\
\text { (2011) [23] }\end{array}$ & & & & $\begin{array}{l}\text { Bradford et al. } \\
\text { (2009) [31] }\end{array}$ & & $\begin{array}{l}\text { Compton \& Boone } \\
\quad \text { (2007) [42] }\end{array}$ \\
\hline & & $\begin{array}{l}\text { Compton \& Boone } \\
\text { (2007) [43] }\end{array}$ & & & & & & \\
\hline & & $\begin{array}{l}\text { Smith \& Heath } \\
\text { (2002) [50] }\end{array}$ & & & & & & \\
\hline \multirow{2}{*}{ Water } & 0 & IPCC (2006) [7] & 0 & - & 0 & - & 0 & - \\
\hline & & Fang (1996) [53] & & & & & & \\
\hline \multirow{4}{*}{$\begin{array}{l}\text { Non-forested } \\
\text { wetland }\end{array}$} & 35.24 & $\begin{array}{l}\text { Bridgham et al. } \\
\quad \text { (2006) [54] }\end{array}$ & 9.18 & $\begin{array}{l}\text { Bridgham et al. } \\
\quad \text { (2006) [54] }\end{array}$ & 99.91 & $\begin{array}{l}\text { Pouyat et al. } \\
\text { (2006) [36] }\end{array}$ & 0 & - \\
\hline & & $\begin{array}{l}\text { Pouyat et al. } \\
\text { (2006) [36] }\end{array}$ & & $\begin{array}{l}\text { InVest User Guide } \\
\text { (2012) [29] }\end{array}$ & & & & \\
\hline & & $\begin{array}{l}\text { Haeseker \& Wills } \\
\quad(2008)[55]\end{array}$ & & & & & & \\
\hline & & Wojick (1999) [56] & & & & & & \\
\hline
\end{tabular}




\begin{tabular}{|c|c|c|c|c|c|c|c|c|}
\hline \multicolumn{9}{|l|}{ Continued } \\
\hline \multirow{2}{*}{$\begin{array}{l}\text { Forested } \\
\text { wetland }\end{array}$} & \multirow[t]{2}{*}{49.28} & $\begin{array}{l}\text { Patton et al. } \\
\text { (2012) [57] }\end{array}$ & 12.83 & $\begin{array}{l}\text { Haeseker \& Wills } \\
\quad \text { (2008) [55] }\end{array}$ & 99.91 & $\begin{array}{l}\text { Patton et al. } \\
\text { (2012) [57] }\end{array}$ & 20.05 & $\begin{array}{l}\text { Patton et al. } \\
\text { (2012) [57] }\end{array}$ \\
\hline & & $\begin{array}{l}\text { Bridgham et al. } \\
\text { (2006) [54] }\end{array}$ & & Wojick (1999) [56] & & & & $\begin{array}{l}\text { Scheller et al } \\
\text { (2011) [58] }\end{array}$ \\
\hline \multirow{2}{*}{$\begin{array}{c}\text { Tidal } \\
\text { wetland }\end{array}$} & \multirow[t]{2}{*}{1.3} & $\begin{array}{l}\text { Patton et al. } \\
\text { (2012) [57] }\end{array}$ & 1.3 & $\begin{array}{l}\text { Scheller et al. } \\
\text { (2011) [58] }\end{array}$ & 240 & $\begin{array}{l}\text { Patton et al. } \\
\text { (2012) [57] }\end{array}$ & 0.7 & $\begin{array}{l}\text { Patton et al. } \\
\text { (2012) [57] }\end{array}$ \\
\hline & & $\begin{array}{l}\text { Bridgham et al. } \\
\quad \text { (2006) [54] }\end{array}$ & & & & $\begin{array}{l}\text { Scheller et al. } \\
\text { (2011) [58] }\end{array}$ & & $\begin{array}{l}\text { Scheller et al } \\
\text { (2011) [58] }\end{array}$ \\
\hline Barren & 0 & IPCC (2006) [7] & 0.33 & $\begin{array}{l}\text { Pouyat et al. } \\
\text { (2006) [36] }\end{array}$ & 0.33 & $\begin{array}{l}\text { Pouyat et al. } \\
\text { (2006) [36] }\end{array}$ & 0 & - \\
\hline \multirow{2}{*}{$\begin{array}{c}\text { Utility } \\
\text { (forests) }\end{array}$} & \multirow[t]{2}{*}{71.8} & $\begin{array}{c}\text { Bradford et al. } \\
\text { (2010) [32] }\end{array}$ & 47.2 & $\begin{array}{c}\text { Bradford et al. } \\
\text { (2010) [32] }\end{array}$ & 65.5 & $\begin{array}{l}\text { McGuire et al. } \\
\text { (1995) [33] }\end{array}$ & 21.9 & $\begin{array}{c}\text { Ghosh (2013) } \\
\text { [59] }\end{array}$ \\
\hline & & $\begin{array}{l}\text { McGuire et al. } \\
\text { (1995) [33] }\end{array}$ & & & & & & \\
\hline
\end{tabular}

paired as input data for InVEST to simulate an amount biomass growth would have contributed to sequestration levels in the absence of land change.

The LUCF C sequestration values were then plotted against total state-wide $\mathrm{CO}_{2}$ emissions for CT tallied by the EPA's State Inventory Tool since 1990. This step determined the relative contribution of sequestered C from each land use category toward reducing emissions as part of CT's overall C budget. Specifically, reductions in forested land use classes changes were plotted against the aggregate loss of bio-sequestration in CT from 1990 to 2010. Differentiating C sequestration values by first, land cover class, and second, by type of forest cover, elucidated their impact of offsetting emissions in the context of a state $\mathrm{C}$ budget and mounting $\mathrm{C}$ offset shortfalls as forested $\mathrm{C}$ sinks were converted to non-forested use over time.

Reductions in forested land use classes were measured against the aggregate loss of bio-sequestration in CT for the period 1985-2010. Sequestered C was found by inputting the inventoried land interval raster data sets of actual LUCF changes with simulated annual C biomass growth values. Biomass growth values for the inventoried years applied to the baseline 1985 raster data map generated an estimate of foregone biomass sequestration. Percent calculations of foregone $\mathrm{C}$ sequestration for the entire twenty-five year period followed Equation (1).

$$
\frac{\sum \text { foregone sequestration }-\sum C \text { sequestration gain }}{\sum \text { foregone sequestration }}
$$

The InVEST program recognizes several limitations implicit to the $C$ sequestration model. a) The use of a simplified $\mathrm{C}$ cycle to model sequestration fails to capture the full dynamics of the natural world; b) $\mathrm{C}$ valuations assume a linear sequestration path, neither gaining or losing $C$ over time, when in reality they change parabolically, since $C$ sequestration occurs at a higher rate initially and decreases over time; and c) The accuracy of model outputs depends on the reliability and detail of input data on land use classes and C pools. C storage estimates within each LUCF class are given as fixed values, though they may differ significantly within a LUCF type according to variables such as elevation, temperature, natural succession or disturbance. Sensitivity analyses were run to simulate uncertainty in the range of biodynamic growth rates as well as on the underlying $C$ stock of the various land classes in order to account for these limitations. Values for forest biomass growth rates derived from scientific literature were projected at ten percent below and above baseline; a range of forty percent below and above baseline for deciduous and coniferous forests accounted for wider uncertainty in biomass growth rates which determine C sequestration across time. The underlying C stock for CT's forested, grass, and sedimentary land categories was modeled explore a range of ten percent below and above baseline estimates.

An additional limitation of the InVEST model is that it prescribes grid cells for a wood-harvest steady-state be assigned a zero sequestration value. The model also fails to capture movements from one pool to another within land class. Projecting age-classes onto the LUCF grid would allow InVEST to more accurately model changes in land attributes as shifts between cells within LUCF categories (principally forested) rather than shifts between LUCF categories alone, since both change $C$ storage values in the process.

The CLEAR series distinguishes "land cover" as detected by the sensors from actual land use, a term which better describes intention or practice occurring at the ground level. Each LandSat cover contains millions of pix- 
els, giving inevitable rise to error. For example, in some cases residential development is camouflaged by forest canopy, causing low-density development to register as a forested pixel at satellite level. It is therefore likely that suburban development is greater than that measured by satellite. CLEAR adjusts for some of these errors; still, uncorrected pixels which misrepresent development will tend to overestimate the amount of forest cover in the state, leading if anything to an underestimation of the amount of $\mathrm{C}$ sequestration lost to development.

As noted in the InVEST methodology guide, the outcome of this research depends strongly on the accuracy of published C stock valuations for terrestrial C pools applicable to CT. However, these values vary from site to site, depending on the actual mix of forest tree species as well as appropriate land use history, soil, climate, and elevation conditions. The rates of biomass accumulation during growth likewise vary significantly. Ecological factors such as local soil moisture, soil chemistry, forest typology, and climatic zone further refine standardized measurements of land-based C flux and are taken into consideration in the selection of $C$ stock values from the literature. Scientific research into some land use categories, however, is scarce (e.g., New England wetlands) and may not reflect state-level specificity in their influence of ecosystem conditions. Data which maps forest species within the deciduous forests of CT were unavailable, consigning the use of a single general value for both baseline $\mathrm{C}$ storage and $\mathrm{C}$ accumulated through forest growth.

All C stock values for modeling land use change were derived from scientific literature published in the last two decades (1992-2012). C stock values published in more recent studies were favored over older sources whenever available. Publication dates for $\mathrm{C}$ stock values also mattered in assessing points of inflection in the bio-chemical dynamics of terrestrial ecosystems being brought on by climate change. Date-specific $\mathrm{C}$ stock values thus aided in quantifying the amounts of $\mathrm{C}$ sequestration lost or gained as land use categories shift. The occasionally contrasting impacts of climate change on bio-geochemical processes can affect photosynthetic rates of $\mathrm{C}$ capture, for instance, as increased levels of plant respiration which accompany higher atmospheric temperatures, soil warming, and inundation of wetlands due to sea level rise. However, such climatic impacts on terrestrial C stocks were not incorporated in the assessment of data over the last twenty-five years.

We assumed forest data gathered in Southern New England is relatively homogenous, given the region's shared history of logging, agriculture, and age of regenerated forest stands. Conservative values were selected over more robust sequestration levels where researchers diverged in their findings. Some estimates of terrestrial $\mathrm{C}$ pools relied on scarcer research assigning $\mathrm{C}$ densities to particular land use categories; inland wetlands exemplified this data shortage, as did C storage systems containing below-ground living biomass. Dead organic matter stocks found in Tier 1, non-forest land-use categories were assigned a zero sequestration value as per IPCC guidance [7]. Therefore, $\mathrm{C}$ stock values used in this study were the best estimates available for these values based on measured biomass per hectare per year for the twelve classes of land use present in CT. Annual changes in $\mathrm{C}$ stocks were built into the five-year intervals inventoried by the CLEAR raster data set.

\section{Results}

Nearly five percent of undeveloped land in Connecticut (CT), the subject of this study, and close to four percent of its forests, was converted to development from 1985 to 2010. The conversion of undeveloped land categories to development, turf, other grasses, and barren land totaled $5.12 \%$ at the end of the twenty-five year study period. However, the percentage reduction in $\mathrm{C}$ sequestration significantly exceeded the $5.12 \%$ rate of land cover change due to the shift from high-density C biomass to low- or no-density C land class cover. Land converted from classes of higher $\mathrm{C}$ density (deciduous forests: $-3.30 \%$, coniferous forests: $-0.32 \%$; forested wetlands: -0.19 , and agricultural fields: -1.27 ) to categories of lower $C$ density (developed: $+3.00 \%$; turf grass, including residential lawns: $+1.51 \%$; other grasses, e.g., highway borders: $+0.61 \%$; and barren land: $+0.19 \%$ ) lowered the state's aggregate $\mathrm{C}$ stock responsible for sequestration.

A static modeling of $\mathrm{C}$ sequestration, assuming no biomass growth within each vegetation type, yielded a net loss of $\mathrm{C}$ sequestration of $38.23 \mathrm{MMTCO}_{2}$, an amount equal to a 3.7\% sequestered $\mathrm{C}$ reduction from 1985 to 2010. Loss of sequestering capacity was led by a 3.3\% reduction in deciduous forest cover. Reduced C closely approximated the $3.83 \%$ forestland converted over the same timeframe. In 1985, forested land classes contributed $84 \%$ of total sequestered C, with deciduous forests providing fully $73 \%$ of total sequestration. By 2010 , C sequestered by deciduous hardwoods had declined by $2 \%$ relative to total $\mathrm{C}$ sequestered by all land cover classes; however, total C sequestration shrank 22.4\% from 1985 to 2010, reflecting the impact on C capture of reduced forest cover. 
However, New England's forests are successional and increasing in biomass. For these dynamic biomass growth scenarios, we assumed forest biomass increased by an annual mean growth rate of $2.5 \mathrm{MgC} / \mathrm{ha}^{-1} / \mathrm{y}^{-1}$ for deciduous forests and 3.0 MgC/ha ${ }^{-1} / \mathrm{y}^{-1}$ for coniferous forests, and thus the rate of potential C sequestration was compounded across time for existing forests. Growth rate scenarios of $\pm 10 \%$ and $\pm 40 \%$ of baseline value captured any significant over- or under-estimation of C stock values for the two principal forest classes-deciduous and coniferous - which essentially determined the outcomes of the InVEST C sequestration simulations. Running scenarios at values for the isolated forest classes conveyed the degree of influence of cumulative biomass stock growth values on overall sequestration goals. Figures 3(a)-(d) depict the results of these various sensitivity analyses run with the land conversion data provided by CLEAR.

Sequestration scenarios held constant all baseline values of $\mathrm{C}$ density per non-forested land cover type while adding a growth model for either or both forest types. The undulation in the early curves showed a decline in C capture owing to an atypically larger loss of forest cover from 1990 to 1995. This dip indicated that the degree of $C$ sequestration from natural biomass growth was not sufficiently robust to overcome the loss of $C$ density due to the higher rate of deforestation during the period. Deforestation in the final C inventory years was slightly slower and, combined with a more robust volume of vegetative growth in this latter period, yielded stronger levels of $\mathrm{C}$ sequestration in the final phase of the confidence interval scenarios.

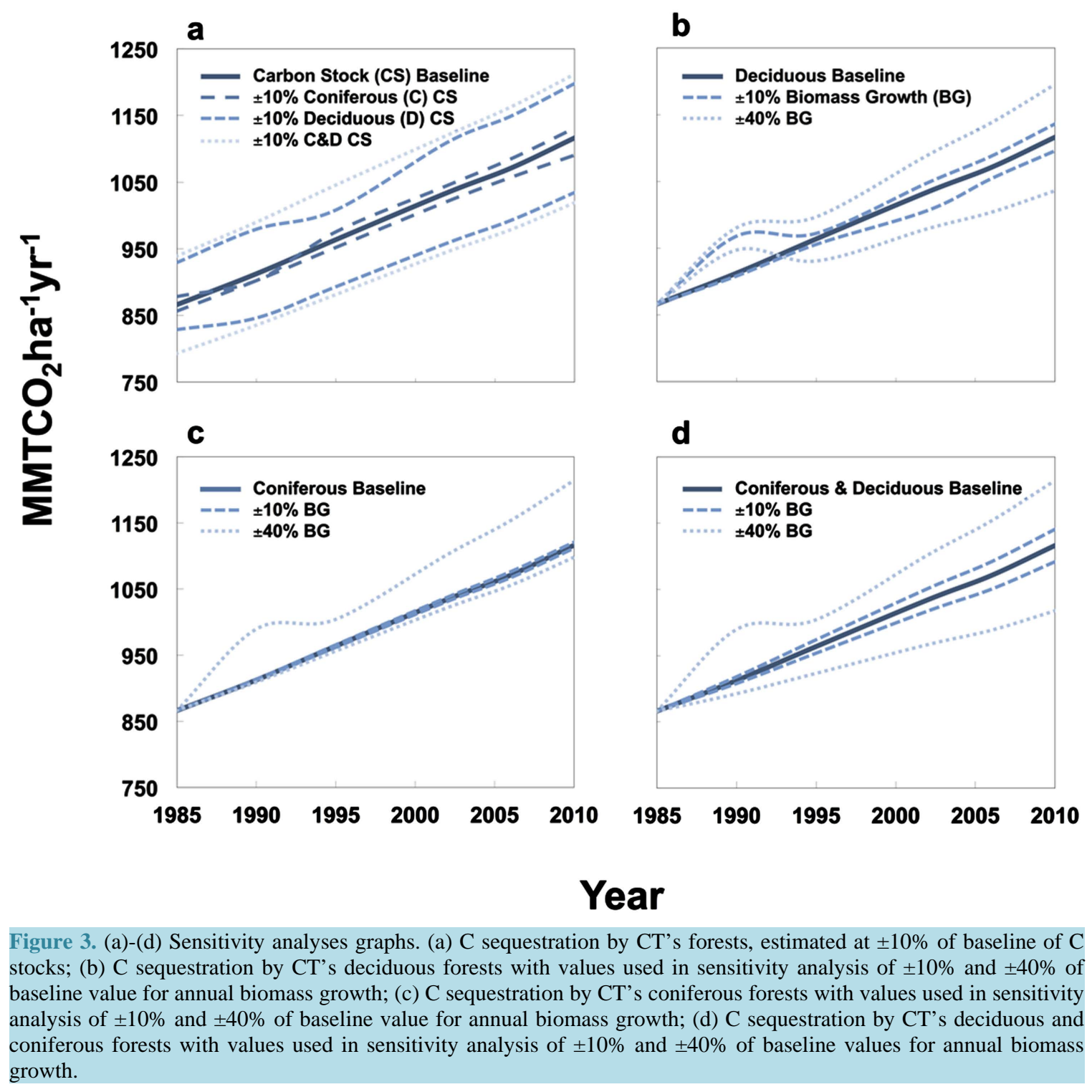


Modeling of all scenarios revealed the $\pm 10 \%$ variation from baseline of combined deciduous and coniferous $\mathrm{C}$ stock to be the prime determinant of long-term C sequestration in Southern New England forests. The slopes of these four sequestration trajectories and their confluence at the 2010 data interval suggested that $\mathrm{C}$ stock values were only overtaken by the most extreme variations from baseline values of $\pm 40 \%$ deciduous and coniferous biomass growth to decide levels of sequestration. The highest overall level of $\mathrm{C}$ sequestered occurred in the scenario describing $40 \%$ above baseline biomass growth by both deciduous and coniferous forests (+40\% D \& C biomass growth) to yield $1214.5 \mathrm{MMTCO}_{2}$. The $+10 \%$ upper limit $\mathrm{C}$ stock for deciduous and coniferous forests $\left(+10 \%\right.$ D \& C C stock) came in nearly at par at $1212 \mathrm{MMTCO}_{2}-$ only $2.5 \mathrm{MMTCO}_{2} \cdot \mathrm{ha}^{-1} \cdot \mathrm{y}^{-1}$ short of the total sequestration for the $+40 \% \mathrm{D} \& \mathrm{C}$ biomass growth scenario. The $+10 \%$ deciduous biomass growth scenario at $1198 \mathrm{MMTCO}_{2}$ ranked third in terms of total sequestration, trailed closely by $+40 \%$ deciduous only biomass growth scenario at $1196 \mathrm{MMTCO}_{2}$.

Based on our sensitivity analyses of variations from baseline values across both $\mathrm{C}$ stock and biomass growth rates, total $\mathrm{C}$ sequestered in $\mathrm{CT}$, in $\mathrm{CO}_{2}$ equivalents fluctuated most widely in response to increases or decreases in underlying $\mathrm{C}$ biomass stock. $\mathrm{A} \pm 10 \%$ variation from baseline value of combined $\mathrm{D} \& \mathrm{C}$ forest stock yields a 47.8 $\mathrm{MMTCO}_{2}$ increase or decrease in total C sequestration [(1212 - 1019)/2), whereas a $\pm 10 \%$ variation in baseline value of deciduous and coniferous annual biomass growth produced a $24.5 \mathrm{MMTCO}_{2}$ difference from baseline C capture [(1214.5 - 1017.7)/2]. C stocks proved nearly twice as influential in determining total $\mathrm{C}$ sequestration across the twenty-five years.

Assumptions of accumulating $\mathrm{C}$ stocks quantitatively pushed total $\mathrm{C}$ sequestration from a 1985 baseline level of $866 \mathrm{MMTCO}_{2} \cdot \mathrm{ha}^{-1} \cdot \mathrm{y}^{-1}$ to a 2010 baseline value which reached $1116 \mathrm{MMTCO}_{2} \cdot \mathrm{ha}^{-1} \cdot \mathrm{y}^{-1}$, or an increment of $250 \mathrm{MMTCO}_{2} \cdot \mathrm{ha}^{-1} \cdot \mathrm{y}^{-1}$. The upper and lower limits of $\pm 10 \%$ of baseline value of forest C stock show fairly predictable levels of C sequestration for the period 1985-2010. Deciduous C stock is the most variable. Sequestered $\mathrm{C}$ for the lower limit of $-10 \%$ baseline $\mathrm{C}$ stock for deciduous and coniferous forests grew by $226 \mathrm{MMTCO}_{2}$ over the 25-year study period, as compared to $252.8 \mathrm{MMTCO}_{2}$ for the $+10 \%$ upper limit of baseline C stock for deciduous and coniferous forests. A $10 \%$ over- or under-estimation of $\mathrm{C}$ stocks produced a difference of 13.5 $\mathrm{MMTCO}_{2}$ from the 2010 baseline, which equates to 35\% of CT's $2010 \mathrm{CO}_{2}$ emissions level (38.12 MMTCO $)$. This result emphasizes the responsiveness of sequestration processes to the underlying change in forest $\mathrm{C}$ stocks.

Modeling results showed that the percentage of foregone sequestration estimated for the baseline model was $17.68 \%$, with modeling extremes ranging from $14.59 \%$ to $23.82 \%$, corresponding to $\pm 40 \%$ deciduous and coniferous biomass growth scenarios, respectively. The highest level of foregone $\mathrm{C}$ sequestration was estimated at over $60 \mathrm{MMTCO}_{2}$ for a $+10 \%$ over baseline of forest $\mathrm{C}$ stocks. Even the most modest measure of foregone $\mathrm{C}$ sequestration (47.34 $\mathrm{MMCTO}_{2}$ from $-10 \%$ variation to baseline $\mathrm{C}$ stock value) in excess of baseline sequestered $\mathrm{C}$ values surpasses accounting of CT's 2010 total fossil fuel emissions (38.12 $\mathrm{MMTCO}_{2}$ ), expressed as $\mathrm{CO}_{2}$ equivalents.

2010 foregone sequestration expresses the difference in $\mathrm{MMTCO}_{2}$ between realized $\mathrm{C}$ sequestered over 1985-2010 and the amount of foregone sequestered $\mathrm{C}$ due to deforestation by the end of the study period. While the total twenty-five year gain in sequestered $\mathrm{C}$ for the baseline scenario was $250 \mathrm{MMTCO}_{2}$, the baseline scenario for foregone C sequestration in CT during 1985-2010, given 1985 land use patterns, is the C equivalent of 303.9 $\mathrm{MMTCO}_{2}$. This baseline scenario values indicate a loss of $53.74 \mathrm{MMTCO}_{2}$, the equivalent of $17.68 \%$ of potential $\mathrm{C}$ sequester for the full twenty-five years as determined by subtracting 1985 estimate of total sequestered C from the 2010 estimate.

Comparing the modeling results of $\mathrm{C}$ sequestration summarized in Figure 4 steers attention to the significant difference between the percentage of forest cover loss (3.83\%) and the percentage of foregone $\mathrm{C}$ sequestration (17.68\%) occurring over this period. The divergence between these percentages owed to the higher $\mathrm{C}$ density of deforested biomass relative to the land cover classes which replaced it. The 3.83\% forest cover reduction represented 190.1 square miles and comprised most of the 5.12\% land use conversion in the categories of developed land, turfgrass and other grasses. The $17.68 \%$ baseline C sequestration reduction rate over the 1985 baseline scenario was 4.62 times greater than the 3.83\% baseline forest conversion rate. Sensitivity analyses of the upper and lower limits to these baseline values reinforce these comparative results to only slightly greater and lesser degrees.

\section{Discussion}

The contrast of twenty-five year history of CT fossil fuel emissions derived from the CT Emissions Summary, 


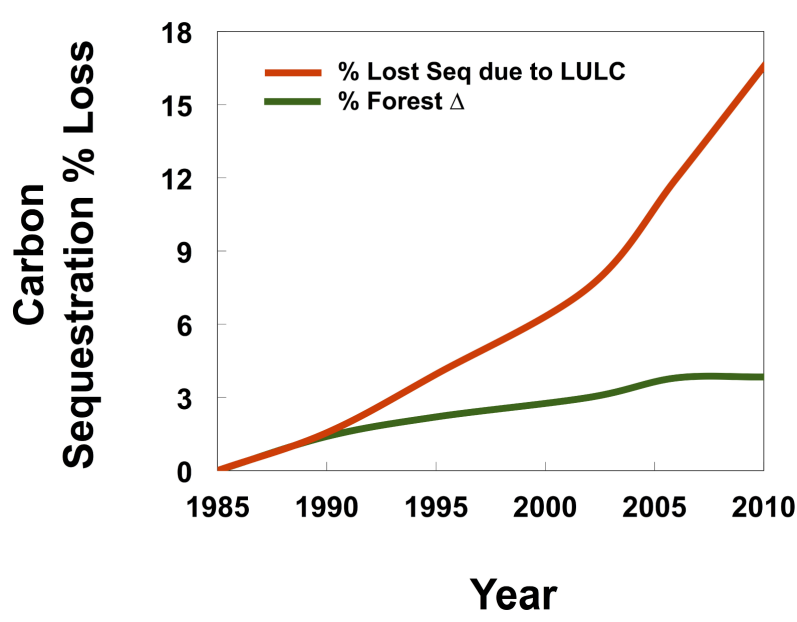

Figure 4. Comparison of percentage loss of forestlands in CT v percentage loss of C sequestration in CT, 1985-2010.

1990-2010 of the EPA State Inventory Tool [3], with foregone opportunities for C sequestration which vegetative land converted to lower $\mathrm{C}$ density failed to capture, is striking. The 2010 fossil fuel emissions total was calculated from data available at the Energy Information Agency [60]. CT's level of annual $\mathrm{CO}_{2}$ emissions has remained fairly stable slightly above or below the $40 \mathrm{MMTCO}_{2}$ mark, with some vicissitudes reflecting state economic conditions and recent policy mandates to curb emissions in light of growing awareness of climate change. The use of 1985 as baseline year for measuring foregone $C$ sequestration corresponds to the start date of CLEAR's land use change inventorying and was thus recorded as zero. Data comparisons showed that the additive loss of sequestered C, significant in its own right, rose over time due to the continued trend in biomass growth, with a surging gap between emissions and foregone sequestration expected in future years.

Comparing sequestered $\mathrm{C}$ against loss of sequestered $\mathrm{C}$ due to recent deforestation revealed the degree of impact CT's land use classes have on state's efforts to mitigate global warming. Modeling of sequestered C from existing biomass growth without land use change rose from 0 in 1985 to $53.74 \mathrm{MMTCO}_{2}$ in 2010. Under this scenario, the annual level of foregone sequestered $\mathrm{C}$ would have surpassed $\mathrm{CO}_{2}$ emissions around the year 2002 and by 2010 would have equated to approximately 140\% of emissions measured in 2010 by CT's most recent GHG inventory [61] (Figure 5).

The expanse of deciduous forests in Southern New England states like CT, amplified by the high level of C they sequester relative to other land uses in the state, positions them as the most impactful land class for our modeling of sequestered C. The high sequestration level of above-ground deciduous biomass (AGB) of baseline value, estimated at $109.8 \mathrm{MgC} \cdot \mathrm{ha}^{-1} \cdot \mathrm{yr}^{-1}$ for 1985 [23] but reaching $172.3 \mathrm{MgC} \cdot \mathrm{ha}^{-1} \cdot \mathrm{yr}^{-1}$ by 2010 according to the dynamic growth modeling, speaks to the influence of these stands as a stabilizer for local C budgets.

The natural processes of forest succession will continue to spur increases in rates of $C$ captured by older forest stands due to changing forest species composition with time. With the exception of natural disturbances, longerlived, shade-tolerant mid- to late-successional species will replace earlier successional species, resulting in increased $\mathrm{C}$ sequestration. This owes to the fact that late successional species absorb more $\mathrm{C}$ due to the higher biomass density in their woody parts. Research on New England forests shows that mid- to late-successional tree species have higher levels of $C$ uptake than their predecessor species [62]. The amount of stored C could more than double in protected forests as they reach maturity [63].

Land conversion and climate change hold the potentially greatest impact to forest landscapes globally [30]. Successional forest growth and regional recovery following a relatively recent history of agricultural abandonment should prevail in driving forest dynamics over the next half century [64]. C sequestration by forest biomass is identified as one of a few climate-related gains to function as a negative feedback loop by buffering continued warming trends [30]. The percentage of modeled sequestration loss in CT over the twenty-five year study period was 4.62 times the percentage loss of high C-density forestland for the same time span. Figure 6(a) and Figure 6(b) express normalized rates of changes for related land cover categories, indicating the high sensitivity of forest biomass contraction to $\mathrm{C}$ sink value. Continued relative land pattern changes as shown here will slow the negative feedback loop C sinks provide and, in contradiction, hasten the impacts of climate change. 


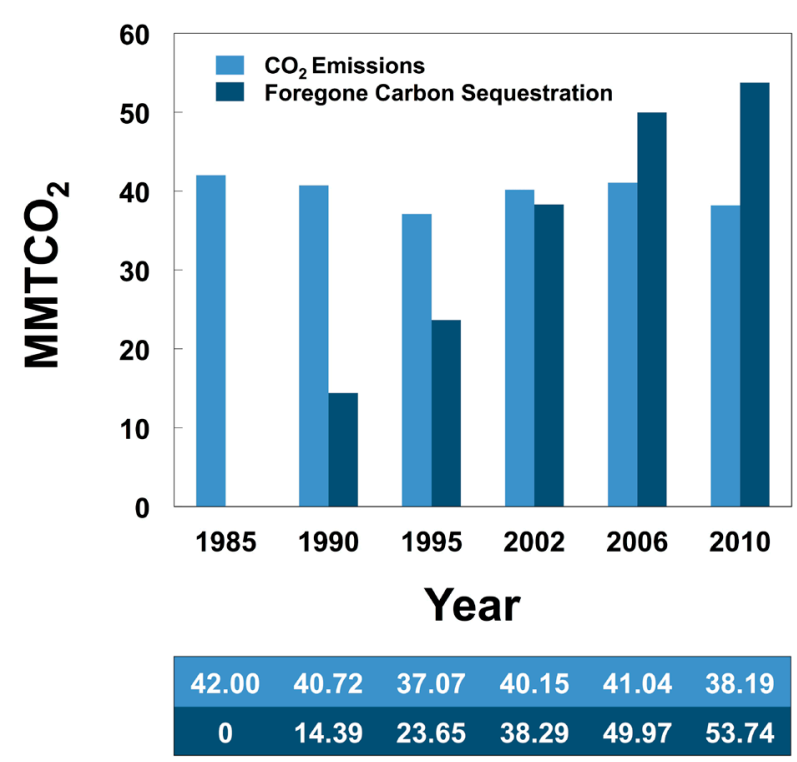

Figure 5. Levels of foregone $\mathrm{C}$ sequestration v levels of annual fossil fuel emissions in CT, 1985-2010.
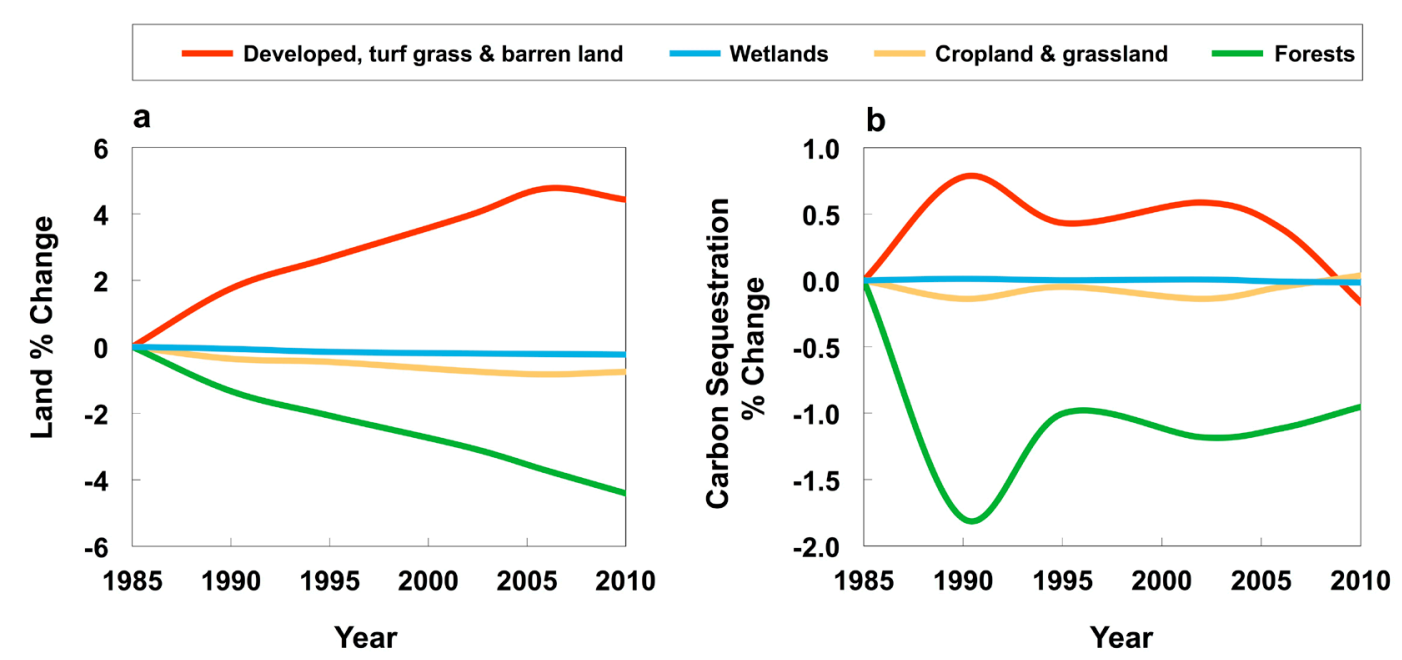

Figure 6. (a) and (b) Percentage of land cover change by grouped LUCF categories relative to all land cover change in CT for the period 1985-2010 (left). Percentage of C sequestration change by grouped LUCF categories relative to total C sequestration change in CT for the period 1985-2010 (right).

Periods of active C sequestration by New England's forest stands have been shown to extend decades beyond previous research assumptions [64]. Despite a century-old legacy of natural forest recovery, Southern New England will continue to see forest $\mathrm{C}$ sequestration for decades into the future. Land conservators, whether public or private agents, must take into account that the equilibrium point for $\mathrm{C}$ storage has not yet been reached. Forest growth and succession will potentially have the largest impact on the aboveground $C$ stock, and this study has shown that deciduous forests in particular have a disproportionate influence on CT's emissions future. Preventative forest conservation ought therefore to play a key role in any global warming solution policy.

Research which identifies land use mismanagement as the enabler of suburban sprawl also proposes the use of satellite land use mapping for better natural resource management [65]. The ecological relevance of mapping for public policy-making is value-additive, embracing habitat conservation, climate adaptation, and water quality management into the process of urban development and regional transportation planning for whole-design land use planning.

Comparing sequestered $\mathrm{C}$ against loss of sequestered $\mathrm{C}$ due to recent deforestation revealed the degree of im- 
pact CT's land use classes have on state's efforts to mitigate global warming. In order to capture GHG remediation through C sink preservation, low-density development in areas of mature, second-growth forests should be discouraged, with development diverted toward renewing the original suburban tracts ringing the urban cores, first built in the 1950s but now suffering from neglect, aging infrastructure and blight. The logic of redirecting development inward holds many merits from a sustainability perspective, among them concentrating population density for transit viability, reducing costs of installation and maintenance for roads and utilities, shortening commuting time and distance, and lowering transportation emissions. Fiscal incentives which reward diverted development can be dually aimed at avoided deforestation, a mechanism largely absent from current climate policy and which itself has not been monetized in terms of economic and social benefits at local and regional planning levels. Avoided deforestation is a major lever for $\mathrm{C}$ abatement and should be considered the equivalent of local negative feedback in the way local emissions contribute positively to climate change.

\section{Conclusions}

This study considered land use change in fine-grain detail to assess the environmental effects of state-wide, incremental land conversion, principally of deciduous forestlands which comprised high-density C storage pools. The CLEAR satellite mapping of CT performed over the last two and a half decades provided cumulative data on LUCF and land cover conversion to new analytical tools adapted to model responses to climate change. CLEAR's land cover data set is to our knowledge the only state-wide mapping project in the United States of this longevity [66]. The application of this data for the analysis presented here demonstrates novel possibilities for quantifying and valuating $\mathrm{C}$ removal in the light of LUCF analysis-a process heretofore disregarded for accounting reasons- to better inform environmental policy choices that come before state and regional governments.

The results of this research prove the importance of land use in achieving a full spectrum of $\mathrm{C}$ accounting which includes both $\mathrm{CO}_{2}$ emissions output and $\mathrm{C}$ sink estimation. Estimates of $\mathrm{C}$ sequestered within all land use categories and the changes within each type create a three-dimensional mosaic of land utility for states to construct global warming solutions. Energy, transportation and environmental policy-makers can benefit from the analysis of land use mapping in order to integrate carbon sink preservation into state policy-making aimed at combating climate change.

\section{Acknowledgements}

We wish to acknowledge the expertise at the institutions which were instrumental for setting this study in motion: the CT Department of Energy and Environmental Protection (DEEP), specifically DEEP Commissioner Dan Esty, Bureau Chief Tracy Babbidge, and climate policy experts Lynn Stoddard and Pete Brunelli; Chet Arnold and Emily Wilson for their pioneering work at CLEAR; Bradley Eichelberger at Woods Institute for the Environment at Stanford University; the staff at the Center for Geographic Analysis at Harvard University; and Jacob Sobstyl, doctoral candidate at MIT, for assistance in modeling our results.

\section{References}

[1] United States Environmental Protection Agency (2014) State and Regional Climate Policy Tracking. US EPA. http://epa.gov/statelocalclimate/state/tracking/index.html

[2] Connecticut General Assembly (2008) Connecticut House Bill 5600, PA 08-98. An Act Concerning Connecticut Global Warming Solutions. State of Connecticut Department of Energy and Environmental Protection Climate Change. http://www.cga.ct.gov/2008/FC/pdf/2008HB-05600-R000755-FC.pdf

[3] United States Environmental Protection Agency (2012) State Inventory Tool for GHG Accounting. http://www.epa.gov/statelocalclimate/state/activities/ghg-inventory.html\#three

[4] United States Environmental Protection Agency (2012) Developing a Greenhouse Gas Inventory. http://epa.gov/statelocalclimate/state/activities/ghg-inventory.html

[5] World Resources Institute/World Business Council for Sustainable Development (2005) The GHG Protocol for Project Accounting. WRI/WBCSD. http://www.ghgprotocol.org/files/ghg_project_protocol.pdf

[6] Colorado State University (n.d.). Agriculture and Land Use National Greenhouse Gas Inventory Software. National Resource Ecology Lab. http://www.nrel.colostate.edu/projects/ALUsoftware

[7] Intergovernmental Panel on Climate Change (2006) Appendix VII: Methodology for Determining Greenhouse Gas In- 
ventories in the Agriculture, Forestry and Other Land Use Sector.

https://www.ipcc.ch/meetings/session25/doc4a4b/vol4.pdf

[8] Connecticut Department of Energy and Environmental Protection (2010) Appendix A: Connecticut 2009 Greenhouse Gas Inventory Data Graphics. Climate Change.

http://www.ct.gov/deep/lib/deep/climatechange/2009_ghg_update__appendix_a.pdf

[9] Sohl, T.L., Sleeter, B.M., Zhu, Z., Sayler, K.L., Bennett, S., Bouchard, M., et al. (2012) A Land-Use and Land-Cover Modeling Strategy to Support a National Assessment of Carbon Stocks and Fluxes. Applied Geography, 34, 111-124. http://dx.doi.org/10.1016/j.apgeog.2011.10.019

[10] U.S. Geological Survey (2014) National Assessment of Ecosystem Carbon Sequestration and Greenhouse Gas Fluxes: Spatially Explicit Modeling of Land Use and Land Cover. U.S. Department of the Interior, Washington DC. http://www.usgs.gov/climate landuse/land carbon/

[11] Solecki, W.D. and Oliveri, C. (2004) Downscaling Climate Change Scenarios in an Urban Land Use Change Model. Journal of Environmental Management, 72, 105-115. http://dx.doi.org/10.1016/j.jenvman.2004.03.014

[12] Jo, J.H., Golden, J.S. and Shin, S.W. (2009) Incorporating Built Environment Factors into Climate Change Mitigation Strategies for Seoul, South Korea: A Sustainable Urban Systems Framework. Habitat International, 33, $267-275$. http://dx.doi.org/10.1016/j.habitatint.2008.10.020

[13] Mashayekh, Y., Jaramillo, P., Samaras, C., Hendrickson, C.T., Blackhurst, M., MacLean, H.L. and Matthews, H.S. (2012) Potentials for Sustainable Transportation in Cities to Alleviate Climate Change Impacts. Environmental Science \& Technology, 46, 2529-2537. http://dx.doi.org/10.1021/es203353q

[14] Heres-Del-Valle, D. and Niemeier, D. (2011) $\mathrm{CO}_{2}$ Emissions: Are Land-Use Changes Enough for California to Reduce VMT? Specification of a Two-Part Model with Instrumental Variables. Transportation Research Part B: Methodological, 45, 150-161. http://dx.doi.org/10.1016/j.trb.2010.04.001

[15] Rudel, T.K., O’Neill, K., Gottlieb, P., McDermott, M. and Hatfield, C. (2011) From Middle to Upper Class Sprawl? Land Use Controls and Changing Patterns of Real Estate Development in Northern New Jersey. Annals of the Association of American Geographers, 101, 609-624. http://dx.doi.org/10.1080/00045608.2011.560062

[16] Willson, R.W. and Brown, K.D. (2008) Carbon Neutrality at the Local Level: Achievable Goal or Fantasy? Journal of the American Planning Association, 74, 497-504. http://dx.doi.org/10.1080/01944360802380431

[17] Sierra Club (2000) Sprawl Costs Us All: How Your Taxes Fuel Suburban Sprawl. Sierra Club, San Francisco.

[18] Center for Land Use Education and Research (2010) Basic Land Cover Information Showing Changes to the Landscape since 1985. Connecticut's Changing Landscape. http://clear.uconn.edu/projects/landscape/index.htm

[19] Stein, S.M., McRoberts, R.E., Alig, R.J., Nelson, M.D., Theobald, D.M., Eley, M. et al. (2005) Forests on the Edge: Housing Development on America's Private Forests. General Technical Report No. PNW-GTR-636, USDA Forest Service, Washington DC. http://www.fs.fed.us/openspace/fote/housing.html

[20] Center for Land Use Education and Research (2012) Interactive Land Cover Maps. http://clear.uconn.edu/data/interactive.htm

[21] Orfield, M. and Luce, T. (2003) Connecticut Metro Patterns: A Regional Agenda for Community and Prosperity in Connecticut. Office of Urban Affairs of the Archdiocese of Hartford, Hartford. http://www.hartfordinfo.org/issues/wsd/SmartGrowth/CT_Metropatterns_English.pdf

[22] United States Census Bureau (2011) 2010 Census Population Profile Maps. http://www.census.gov/geo/www/maps/2010_census_profile_maps/census_profile_2010_main.html

[23] Butler, B.J., Barnett, C.J., Crocker, S.J., Domke, G.M., Gormanson, D., Hill, W.N., et al. (2011) The Forests of Southern New England, 2007: A Report on the Forest Resources of Connecticut, Massachusetts, and Rhode Island. USDA Forest Service, Northern Research Station, Newtown Square, Vol. 55, 1-48.

[24] Theobald, D.M. (2005) Landscape Patterns of Exurban Growth in the USA from 1980 to 2020. Ecology and Society, 10, 32. http://www.ecologyandsociety.org/vol10/iss1/art32/

[25] Martinuzzi, S., Gould, W.A. and Ramos González, O.M. (2007) Land Development, Land Use, and Urban Sprawl in Puerto Rico Integrating Remote Sensing and Population Census Data. Landscape and Urban Planning, 79, $288-297$. http://www.sciencedirect.com/science/article/pii/S0169204606000478 http://dx.doi.org/10.1016/j.landurbplan.2006.02.014

[26] Jaeger, J.A.G., Bertiller, R., Schwick, C. and Kienast, F. (2010) Suitability Criteria for Measures of Urban Sprawl. Ecological Indicators, 10, 397-406.

http://gpe.concordia.ca/documents/Poster\%20Landscape\%20Fragmentation\%20in\%20Europe.pdf http://dx.doi.org/10.1016/j.ecolind.2009.07.007

[27] Zeng, H., Sui, D.Z. and Li, S. (2005) Linking Urban Field Theory with GIS and Remote Sensing to Detect Signatures 
of Rapid Urbanization on the Landscape: Toward a New Approach for Characterizing Urban Sprawl. Urban Geography, 26, 410-434. http://dx.doi.org/10.2747/0272-3638.26.5.410

[28] Wood Institute for the Environment, Stanford University (2012) InVEST Model. http://ncp-dev.stanford.edu/ dataportal/invest-releases/documentation/current_release/carbonstorage.html

[29] Wood Institute for the Environment, Stanford University (2011) Carbon Storage and Sequestration, the Natural Capital Project. Prod. Stanford University, Stanford.

http://ncp-dev.stanford.edu/ dataportal/invest-releases/documentation/current_release/carbonstorage.html

[30] Thompson, J.R., Foster, D.R., Scheller, R. and Kittredge, D. (2011) The Influence of Land Use and Climate Change on Forest Biomass and Composition in Massachusetts, USA. Ecological Applications, 21, 2425-2444.

[31] Bradford, J.B., Weishampel, P., Smith, M.L., Kolka, R., Birdsey, R.A., Ollinger, S.V. and Ryan, M.G. (2009) Detrital Carbon Pools in Temperate Forests: Magnitude and Potential for Landscape-Scale Assessment. Canadian Journal of Research, 39, 802-813. http://dx.doi.org/10.1139/X09-010

[32] Bradford, J.B., Weishampel, P., Smith, M.-L., Kolka, R., Birdsey, R.A., Ollinger, S.V. and Ryan, M.G. (2010) Carbon Pools and Fluxes in Small Temperate Forest Landscapes: Variability and Implications for Sampling Design. Forest Ecology and Management, 259, 1245-1254. http://www.fs.fed.us/rm/pubs other/rmrs 2010 bradford j001.pdf http://dx.doi.org/10.1016/j.foreco.2009.04.009

[33] McGuire, A.D., Melillo, J.M., Kicklighter, D.W and Joyce, L.A. (1995) Equilibrium Responses of Soil Carbon to Climate Change: Empirical and Process-Based Estimates. Journal of Biogeography, 22, 785. http://dx.doi.org/10.2307/2845980

[34] Wofsy, S.C., Goulden, M.L., Munger, J.W., Fan, S.M., Bakwin, P.S., Daube, B.C., et al. (1993) Net Exchange of CO $_{2}$ in a Mid-Latitude Forest. Science, 260, 1314-1317. http://dx.doi.org/10.1126/science.260.5112.1314

[35] Bugbee, G. (2012) Soil Carbon Values for CT.

[36] Pouyat, R.V., Yesilonis, I.D. and Nowak, D.J. (2006) Carbon Storage by Urban Soils in the United States. Journal of Environmental Quality, 35, 1566-1575. http://dx.doi.org/10.2134/jeq2005.0215

[37] Pouyat, R., Groffman, P., Yesilonis, I. and Hernandez, L. (2002) Soil Carbon Pools and Fluxes in Urban Ecosystems. Environmental Pollution, 116, S107-S118. http://dx.doi.org/10.1016/S0269-7491(01)00263-9

[38] Qian, Y. and Follett, R. (2010) Carbon Dynamics and Sequestration in Urban Turf Grass Ecosystems. In: Lal, R. and Augustin, B., Eds., Carbon Sequestration in Urban Ecosystems, Springer, Dordrecht, 161-172. http://dx.doi.org/10.1007/978-94-007-2366-5_8

[39] Rossi, F. (2010) Turf Grass Carbon Pools.

[40] Post, W.M. and Kwon, K.C. (2005) Soil Carbon Sequestration and Land-Use Change: Processes and Potential. Global Change Biology, 6, 317-328. http://cdiac.esd.ornl.gov/programs/CSEQ/terrestrial/postkwon2000/postkwon2000.html http://dx.doi.org/10.1046/j.1365-2486.2000.00308.x

[41] Qian, Y., Follett, R.F. and Kimble, J.M. (2010) Soil Organic Carbon Input from Urban Turf Grasses. Soil Science Society of America Journal, 74, 366-371. http://dx.doi.org/10.2136/sssaj2009.0075

[42] Compton, J.E. and Boone, R.D. (2000) Agricultural Legacies on Soil Carbon and Nitrogen. Ecology, 8, $2317-2330$.

[43] Conant, R.T., Paustian, K. and Elliott, E.T. (2001) Grassland Management and Conversion into Grassland: Effects on Soil Carbon. Ecological Applications, 11, 343-355. http://cdiac.esd.ornl.gov/programs/CSEQ/terrestrial/Conant2001/conant2001.html http://dx.doi.org/10.1890/1051-0761(2001)011[0343:GMACIG]2.0.CO;2

[44] Birdsey, R. and Heath, L.S. (1992) Forest Inventory Data, Models, and Assumptions for Monitoring Carbon Flux. In: Lal, R. and Follett, R.F., Eds., Soil Carbon Sequestration and the Greenhouse Effect, Soil Science Society of America, Madison.

[45] Lal, R., Follett, R.F., Kimble, J. and Cole, C.V. (1999) Managing US Cropland to Sequester Carbon in Soil. Journal of Soil and Water Conservation, 54, 374-381.

[46] Raciti, S.M., Fahey, T.J., Thomas, R.Q., Woodbury, P.B., Driscoll, C.T., Carranti, F.J., et al. (2012) Local-Scale Carbon Budgets and Mitigation Opportunities for the Northeastern United States. BioScience, 62, 23-38. http://dx.doi.org/10.1525/bio.2012.62.1.7

[47] West, T.O. and Post, W.M. (2002) Soil Organic Carbon Sequestration by Tillage and Crop Rotation: A Global Data Analysis. Soil Science Society of America Journal, 66, 1930. http://dx.doi.org/10.2136/sssaj2002.1930

[48] Davidson, E.A., Savagea, K., Bolstadb, P., et al. (2002) Belowground Carbon Allocation in Forests Estimated from Litterfall and IRGA-Based Soil Respiration Measurements. Agricultural and Forest Meteorology, 113, 39-51. http://dx.doi.org/10.1016/S0168-1923(02)00101-6 
[49] Lal, R. (2008) Carbon Sequestration. Philosophical Transactions of the Royal Society B: Biological Sciences, 363, 815830. http://dx.doi.org/10.1098/rstb.2007.2185

[50] Smith, J.E. and Heath, L.S. (2002) A Model of Forest Floor Carbon Mass for United States Forest Types. US Department of Agriculture, Forest Service, Northeastern Research Station, Newtown Square, 37.

[51] Luyssaert, S., Inglima, I., Jung, M., Richardson, A.D., Reichstein, M., Papale, D., et al. (2007) $\mathrm{CO}_{2}$ Balance of Boreal, Temperate, and Tropical Forests Derived from a Global Database. Global Change Biology, 113, 2509-2537. http://dx.doi.org/10.1111/j.1365-2486.2007.01439.x

[52] Lal, R. (2005) Forest Soils and Carbon Sequestration. Forest Ecology and Management, 220, 242-258. http://dx.doi.org/10.1016/j.foreco.2005.08.015

[53] Fang, J., Chen, A., Peng, C., Zhao, S. and Ci, L. (2001) Changes in Forest Biomass Carbon Storage in China between 1949 and 1998. Science, 292, 2320-2322. http://dx.doi.org/10.1126/science.1058629

[54] Bridgham, S.D., Megonigal, J.P., Keller, J.K., Bliss, N.B. and Trettin, C. (2006) The Carbon Balance of North American. Wetlands, 26, 889-916. http://dx.doi.org/10.1672/0277-5212(2006)26[889:TCBONA]2.0.CO;2

[55] Haeseker, S.L. and Wills, D. (2008) Evaluation of Two Release Operations at Bonneville Dam on the Smolt-to-Adult Survival of Spring Creek National Fish Hatchery Fall Chinook Salmon. Columbia River Fishery Program Office US Fish and Wildlife Service, Vancouver.

[56] Wojick, D.E. (1999) Carbon Storage in Soil, the Ultimate No-Regrets Policy? A Report to Greening Earth Society. http://lists.ibiblio.org/pipermail/permaculture/2002-November/017349.html

[57] Patton, D., Moore, R., Covich, A.P. and Bergstrom, J.C. (2013) Ex-Post Reliability Assessment of Benefit Transfer Valuation Estimates of Wetland Ecosystem Service Supported by Okefenokee National Wildlife Refuge. Social Science Research Network, Rochester, NY, SSRN Scholarly Paper ID: 2294080.

[58] Scheller, R.M., Tuyl, S.V., Clark, K.L., Hom, J. and Puma, I.L. (2011) Carbon Sequestration in the New Jersey Pine Barrens under Different Scenarios of Fire Management. Ecosystems, 14, 987-1004. http://dx.doi.org/10.1007/s10021-011-9462-6

[59] Ghosh, D. (2012) Utility Forest Maintenance.

[60] United States Energy Information Agency (2012) Connecticut State Profile and Energy Estimates. Department of Energy, Washington DC. http://www.eia.gov/beta/state/?sid=CT

[61] Connecticut Department of Energy and Environmental Protection (2010) Appendix B: 2009. Connnecticut's Greenhouse Gas Inventory Data Graphics. Climate Change. http://www.ct.gov/deep/lib/deep/climatechange/2009_ghg_update_-_appendix_b.pdf

[62] Hadley, J.O., O’Keefe, J., Munger, J.W., Hollinger, D.Y. and Richardon, A.D. (2008) Phenology of Forest-Atmosphere Carbon Exchange for Deciduous and Coniferous Forests in Southern and Northern New England. In: Phenology of Ecosystem Processes, Springer, New York, 119-141.

[63] Foster, D.R., Donohue, B.M., Kittredge, D.B., Lambert, K.F., Hunter, M.L., Hall, B.R., et al. (2010) Wildlands and Woodlands: A Vision for the New England Landscape. Harvard Forest, Harvard University Press, Cambridge.

[64] Foster, D.R. and Aber, J.D. (2004) Forests in Time: The Environmental Consequences of 1000 Years of Change in New England. Yale University Press, New Haven.

[65] Holdt, B.M., Civco, D.L. and Hurd, J.D. (2004) Forest Fragmentation Due to Land Parcelization and Subdivision: A Remote Sensing and GIS Analysis. Proceedings of the ASPRS Annual Convention, Denver, 23-28 May 2004. http://clear.uconn.edu/publications/research/tech papers/Holdt et al ASPRS2004.pdf

[66] Arnold, C. and Wilson, E. (2012) Using CLEAR Long-Term Data to Map Carbon Sequestration Change in Connecticut. 
Scientific Research Publishing (SCIRP) is one of the largest Open Access journal publishers. It is currently publishing more than 200 open access, online, peer-reviewed journals covering a wide range of academic disciplines. SCIRP serves the worldwide academic communities and contributes to the progress and application of science with its publication.

Other selected journals from SCIRP are listed as below. Submit your manuscript to us via either submit@scirp.org or Online Submission Portal.
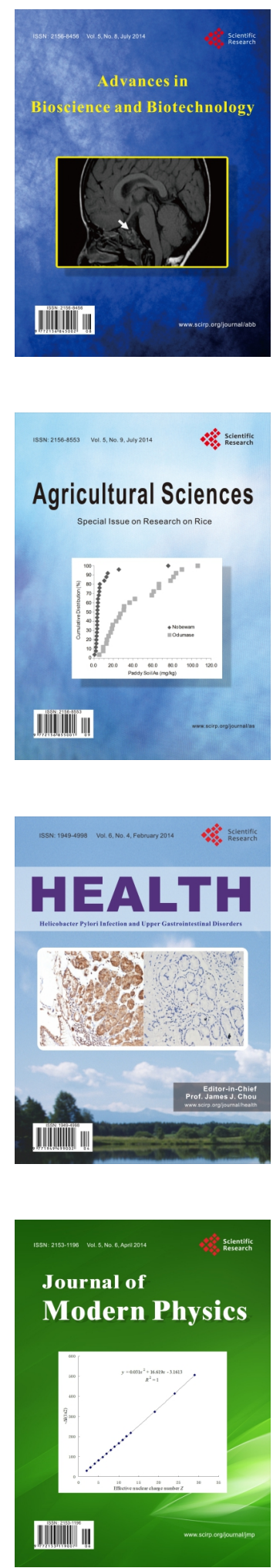
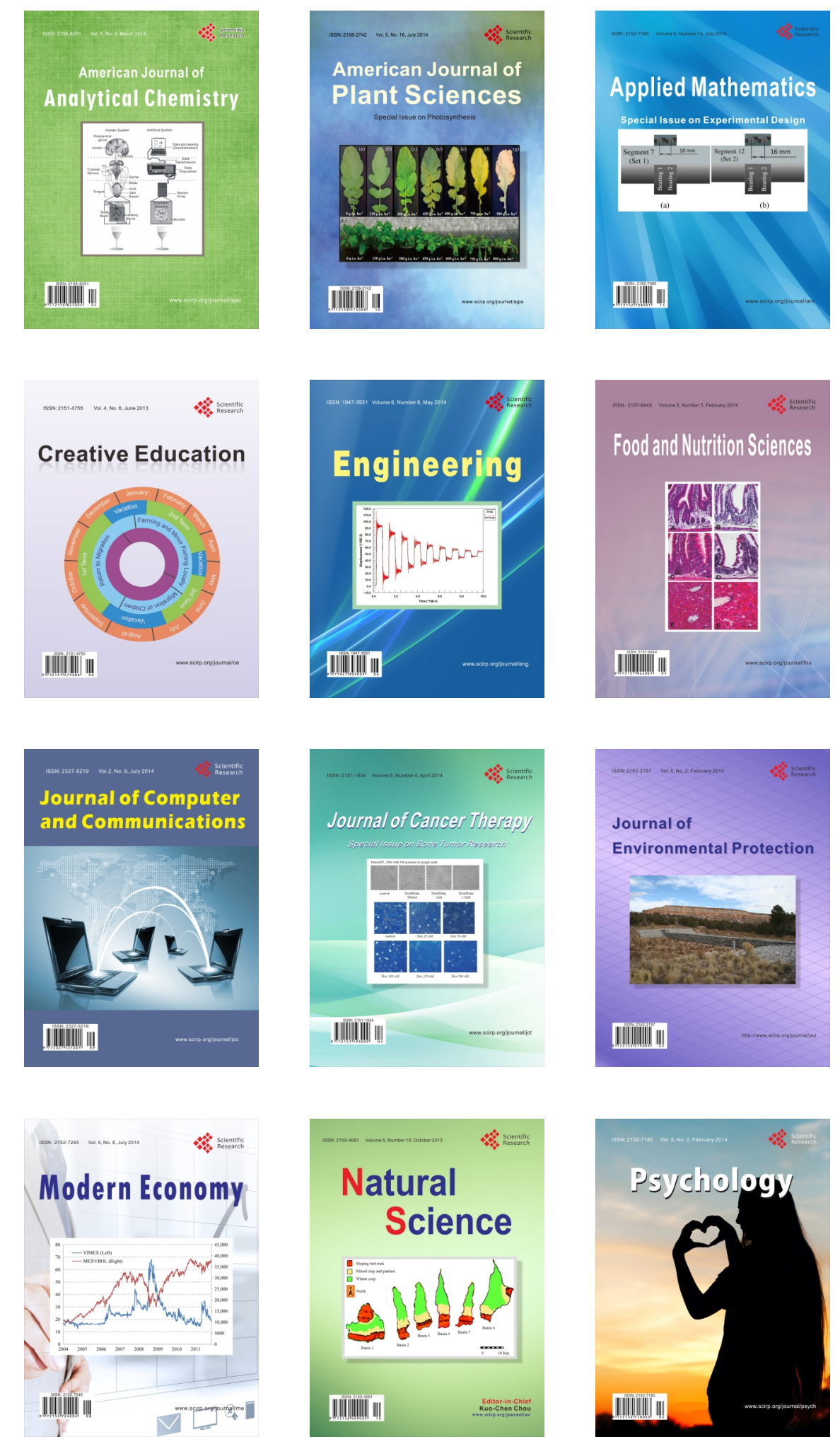